\title{
Increasing demand for reproductive health services in a Peruvian clinic
}

Federico R. Leon

Anibal Velasquez

Lissette Jimenez

Alicia Calderon

Follow this and additional works at: https://knowledgecommons.popcouncil.org/departments_sbsr-rh

Part of the Demography, Population, and Ecology Commons, Health Services Research Commons, International Public Health Commons, and the Women's Health Commons How does access to this work benefit you? Let us know!

\section{Recommended Citation}

Leon, Federico R., Anibal Velasquez, Lissette Jimenez, and Alicia Calderon. 1998. "Increasing demand for reproductive health services in a Peruvian clinic," INOPAL Final Report. Washington, DC: Population Council. 


\section{INCREASING DEMAND FOR REPRODUCTIVE HEALTH SERVICES}

\section{IN A PERUVIAN CLINIC}

Federico R. León, Aníbal Velásquez, Lissette Jiménez, and Alicia Calderón

13 April 1998

Federico León is a Program Associate with the Population Council, Lima. Aníbal Velásquez is Director of Evaluation and Lissette Jiménez is Assistant Researcher, both with INPPARES, Lima. Alicia Calderón is a Catholic University Psychology Intern with the Population Council, Lima. 


\title{
INCREASING DEMAND FOR REPRODUCTIVE HEALTH SERVICES IN A PERUVIAN CLINIC
}

\begin{abstract}
Family planning organizations such as INPPARES have incorporated reproductive health services but have not as yet advertised them effectively. Accordingly, part of their clinic infrastructure remains idle. To increase the demand for such services INPPARES developed an interactive threefold pamphlet that asked questions about the client's health and informed her about the various services at its Patres clinic in Lima, Peru. In a posttest-only true experiment conducted to evaluate the impact of the folder on client behavior, 20 calendar days were randomly assigned to the interactive IEC condition $(n=10)$ or to a control group $(n=10)$, and the cohorts of new clients on those days (with $n$ s ranging from 15 to 39) were used as units of analysis. The group under interactive IEC showed significantly higher values than the control group for the four dependent variables in the study: number of services purchased on the day of the first visit, amount in Peruvian soles paid on that day, number of services purchased over the following 30 days, and amount in soles paid during that period. INPPARES could attain yearly revenues amounting to $\$ 40,000$ as a direct effect of using the interactive pamphlet at its Patres clinic.
\end{abstract}




\section{INTRODUCTION}

Over the past few years, well-established family planning organizations in developing countries such as INPPARES, the IPPF affiliate in Peru, have strived to implement the Cairo Agenda (United Nations, 1995). In the process of including reproductive health in family planning care, they have dedicated human resources and infrastructure to provide reproductive health services that in the past were seldom offered. The problems these organizations now face is to increase utilization of the newly available reproductive health care. Currently, clients seeking family planning services may leave clinics unaware of the other reproductive health care provided. At the main INPPARES clinic, for instance, when clients were asked to name new services they would like to see the clinic offer, 34\% mentioned treatment of STDs, cancer screening, antenatal control and other reproductive health services already offered by the clinic (Velásquez et al., 1996).

Lack of knowledge and the consequent underutilization of newly installed capacity have serious financial implications for nongovernmental organizations in the process of becoming independent of external support. At a time when international donors are phasing out their financial assistance, the partially idle infrastructure that these NGOs maintain is a needless drain of their scant resources.

\section{Interactive IEC as a Solution}

Velásquez et al. (1997) proposed a solution to the underutilization of reproductive health services offered by Patres, the main INPPARES clinic in Lima. They developed an interactive threefold pamphlet that visitors to the clinic could use to help decide if they needed some of the reproductive health services available on site. Based on an algorithm developed for use in Mexico and Guatemala by providers (Vernon \& Ottolenghi, 1996), the pamphlet asked the client (1) whether she had been screened for cancer in the past year; (2) she or her partner showed symptoms of STDs; and (3) if she had other reproductive health problems. The folder informed the client about the appropriate services offered by Patres. Clinic receptionists were trained to give 
the threefold to each new client and explain its contents using a flipchart.

Velásquez et al. (1997) applied this approach over 10 days chosen at random from March 6 through April 4, 1997 and used the other 10 working days of this period as a control. The purpose of the study was to determine if the interactive IEC would increase utilization and clinic revenues. Unfortunately, the results were confounded by a concomitant price reduction of the promoted services. Given the contamination, it was impossible to isolate the impact of the interactive IEC from the impact of the reduced prices. Thus, INPPARES decided to repeat the study once again, this time avoiding contamination, to test the hypothesis that the interactive IEC would (a) increase service demand; and (b) increase clinic income.

\section{METHODOLOGY}

Like in the original study, 20 calendar days were randomly assigned to the interactive IEC condition and the control group. However, in contrast to the previous approach, prices were left unchanged and the study utilized a true experimental design in which cohort data (the aggregate of clients coming to Patres on a given day) were the units of analysis.

\section{Assignment to Treatments}

The working days of four contiguous weeks from October 13th through November 7th, 1997 were chosen as the randomization units of study. A stratified random assignment of calendar days to experimental conditions was conducted to insure that the days of the week were equally represented in the experimental and control groups (e.g., two Mondays under interactive IEC and two Mondays as controls, etc.).

On the days chosen for the intervention, each new client entering the Patres clinic was directed to the Admissions counter, where a trained receptionist handed her the threefold pamphlet and explained its contents using a flipchart. The pamphlet offered early detection of gynecological cancers, diagnosis and treatment of STDs, as well as general medical, pediatric, and psychological counseling. Once the client asked for the service(s) she wanted, the receptionist entered her

personal data in the Clinic Administration System and directed the client to the Cashier to pay for 
the services. The Cashier, in turn, entered the amount paid per service item.

The procedure was the same on control days, with the difference that no threefold pamphlet was given to the patient. The price of each reproductive health, family planning, or other health consultation was kept at 19 soles (about \$7) both on the intervention and control days. Similar was the case of the more expensive services (ecography, IUD insertion, etc.).

\section{Subjects and Measures}

INPPARES defines a new client as any person for whom a new clinical history is opened - either a first-time visitor to the clinic or someone returning after a period of five years or longer. Upon completion of the intervention period, four sets of new client data were retrieved from the Clinic Administration System: (a) number of services purchased the day on which the clinic history was opened, (b) total amount paid in soles on that day, (c) number of services purchased over the following 30 days, and (d) total amount paid in soles during this follow-up period.

\section{RESULTS}

Table 1 shows the number of new clients and mean number of services purchased and amount paid, both on the first visit and during the 30-day follow-up period, by cohort and treatment group. Owing to the markedly non-normal distributions, a non-parametric statistic, Mann-Whitney's $U$-test, was selected for hypothesis-testing.

\section{First Visit}

Figure 1 shows the means and medians computed across cohorts in the first-visit data of Table 1. In each of the four comparisons, the experimental group shows larger values than the control group. The Mann-Whitney $U$ s were 19.5 for services and 20.0 for soles, significant at the $p<.01$ and .02 levels (one-tailed), respectively.

\section{Follow-Up}

Figure 2 shows the means and medians computed across cohorts on the follow-up data of 
Table 1. Again, in each of the four comparisons, the experimental group showed higher Table 1 Number of new clients and mean number of services purchased and amount paid in soles per case on the first visit and during the 30-day follow-up period, per cohort and treatment condition, INPPARES Patres clinic, Lima, Peru

\begin{tabular}{|c|c|c|c|c|c|}
\hline \multirow[b]{2}{*}{ Cohort and Treatment } & \multirow{2}{*}{$\begin{array}{c}\text { New } \\
\text { Clients }\end{array}$} & \multicolumn{2}{|l|}{ First Visit } & \multicolumn{2}{|l|}{ Follow-Up } \\
\hline & & Services & Soles & Services & Soles \\
\hline \multicolumn{6}{|l|}{ Interactive IEC $(n=10)$} \\
\hline Tuesday, Oct. 14 & 22 & 1.864 & 36.840 & 0.954 & 21.770 \\
\hline Wednesday, Oct. 15 & 32 & 1.719 & 33.375 & 1.375 & 34.969 \\
\hline Monday, Oct. 20 & 28 & 1.821 & 36.893 & 1.286 & 36.215 \\
\hline Thursday, Oct. 23 & 23 & 1.950 & 62.435 & 0.609 & 18.130 \\
\hline Friday, Oct. 24 & 15 & 1.467 & 29.600 & 0.933 & 24.267 \\
\hline Wednesday, Oct. 29 & 23 & 1.696 & 43.783 & 0.956 & 27.217 \\
\hline Monday, Nov. 3 & 33 & 1.788 & 43.545 & 0.636 & 20.182 \\
\hline Tuesday, Nov. 4 & 39 & 2.026 & 47.846 & 0.744 & 22.590 \\
\hline Thursday, Nov. 6 & 23 & 1.909 & 44.091 & 0.591 & 22.954 \\
\hline Friday, Nov. 7 & 24 & 1.458 & 28.875 & 1.167 & 81.167 \\
\hline \multicolumn{6}{|l|}{ Control $(n=10)$} \\
\hline Monday, Oct. 13 & 30 & 1.800 & 33.433 & 0.500 & 12.800 \\
\hline Thursday, Oct. 16 & 19 & 1.500 & 27.333 & 0.833 & 21.333 \\
\hline Friday, Oct. 17 & 31 & 1.677 & 45.161 & 1.064 & 15.129 \\
\hline Tuesday, Oct. 21 & 20 & 1.500 & 31.250 & 0.350 & 17.500 \\
\hline Wednesday, Oct. 22 & 24 & 1.458 & 26.542 & 0.708 & 21.625 \\
\hline Monday, Oct. 27 & 19 & 1.579 & 28.684 & 0.210 & 4.210 \\
\hline Tuesday, Oct. 28 & 17 & 1.412 & 26.941 & 0.647 & 34.176 \\
\hline Thursday, Oct. 30 & 29 & 1.552 & 27.137 & 0.379 & 27.483 \\
\hline Friday, Oct. 31 & 32 & 1.562 & 33.219 & 0.719 & 18.531 \\
\hline Wednesday, Nov. 5 & 30 & 1.533 & 39.267 & 0.233 & 12.000 \\
\hline
\end{tabular}


Figure 1 First Visit: Means and Medians for Services and Soles for Cohorts, by Treatment Condition $(n=10)$

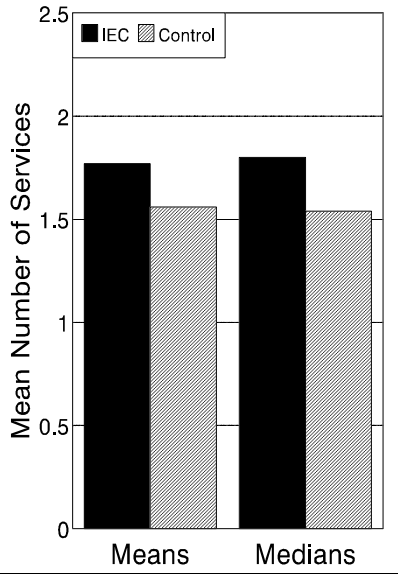

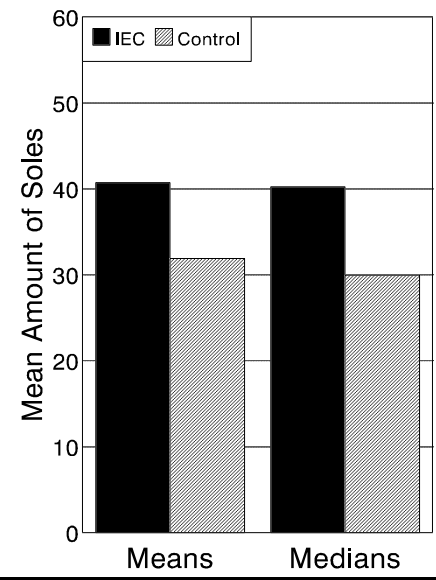

values. The Mann-Whitney Us were 20.0 for services and 19.0 for soles, significant, respectively, at the $p<$ .02 and .01 levels (one-tailed).

\section{Impact on Clinic Revenues}

During the month of the intervention and the 30-day followup period, the Patres clinic earned a total of $18,384.48$ soles from the experimental group and $12,920.37$

soles from the control group. ${ }^{1}$ The difference $(5,464.41$ soles) can be attributed to effects of the interactive IEC. We can assume that, had the pamphlet been given to both groups, this increase in revenue to the Patres clinic would have doubled $(10,928.22$ soles $)$. Counting the number of copies of the pamphlet made and the time taken by the Admissions clerk to explain its use, total expenses would come to less than $1,928.22$ soles. This means a net gain of at least 9,000 soles

Figure 2 Follow-Up: Means and Medians for Services and Soles for Cohorts, by Treatment Condition $(n=10)$

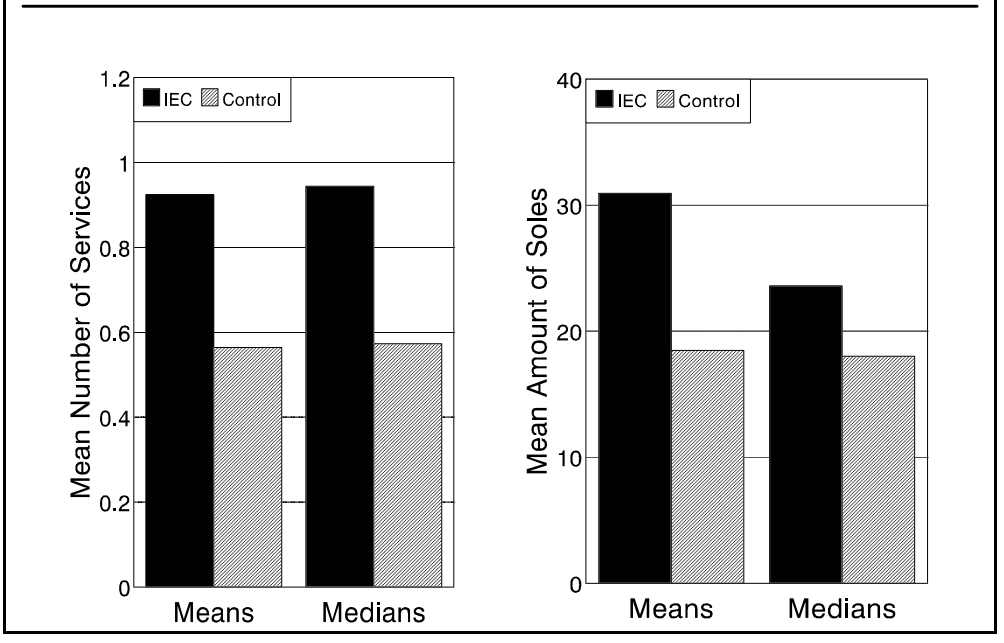

could have been obtained. If this trend were maintained throughout one year, INPPARES would stand to gain 108,000 soles or about $\$ 40,000$ from the use of a simple threefold material. This is a considerable return on the investment. A more encompassing evaluation would consider the contribution of the pamphlet to the possible change of INPPARES' image from a family planning provider to a provider of family planning and reproductive health services. 


\section{DISCUSSION}

Shrinking donor contributions to family planning in Latin America are forcing NGOs to become more self-sufficient financially. Three strategies are available to improve a program's financial sustainability. Cost control seeks to improve financial status by making better use of existing resources, cost recovery consists of charging fees for existing services, and income generation seeks to identify market niches that a program can exploit. INPPARES sought an IEC solution to a situation in which resources were not being fully used, and it had cost recovery and income generation components. The study showed how program management can use simple solutions creatively to cause important improvements. Furthermore, the solution tested here could transcend the physical limits of the clinic and be used in outreach efforts.

This study has some implications for the institutionalization of operations research in family planning/reproductive health programs. Whereas operations research is being increasingly used to test new solutions to improve the financial sustainability of programs (e.g., Bratt et al, 1998), most operations research studies still are dependent on external funding. The costs of the

present study, however, were financed by INPPARES and thus this represents a pioneering effort to invest in operations research. Second, the simplicity of the methodological approach reinforced the staff's commitment to using data for decisionmaking. By employing modern software and high speed computers, researchers may be tempted to select complicated multivariate analyses to test simple relationships between variables, the cost being the loss of contact with the datum. In contrast, the rather small database used in this study (Table 1) allowed both researchers and administrators to have close contact with the data and fully understand their meaning and practical implications. As a consequence, INPPARES decided to maintain the use of the interactive pamphlet on a permanent basis.

Finally, this study demonstrated that an NGO may find programmatic solutions that integrate institutional ends usually viewed as opposite courses of action. Generally, efforts to improve access to services are viewed as antagonistic with those to increase the financial sustainability of programs. In this study, an interactive pamphlet improved clinic revenues and at the same time facilitated access to reproductive health services usually ignored by the family 
planning clients of Patres.

\section{NOTES}

${ }^{1}$ Actually, these are adjusted totals. Instead of using the actual $n s$ of the experimental and control groups, we used the average $n=26.5$ per cohort in the calculations. Otherwise, cohort size, which was a factor independent of the treatment, would have biased the totals.

\section{ACKNOWLEDGMENTS}

This study is a follow-up of a research project devised by Aníbal Velásquez, Adolfo Rechkemer, María Elena Planas, and Rubén Durand with the technical assistance of Ricardo Vernon that was sponsored by the Operations Research Workshop of the Institute of Population Studies (IEPO) of Universidad Peruana Cayetano Heredia (Lima, December 1996). The workshop was part of IEPO's program of institutionalization of operations research in Peru sponsored by the Population Council's INOPAL III Project, in turn funded by the United States Agency for International Development.

This study was financed by INPPARES and received technical assistance from INOPAL.

The authors appreciate the comments of Jim Foreit and Bob Miller on an earlier manuscript.

\section{REFERENCES}

Bratt, J. H., J. R. Foreit, \& T. de Vargas (1998). "Three strategies to promote sustainabilityof CEMOPLAF clinics in Ecuador." Studies in Family Planning 29, 1: 58-68.

United Nations (1995). Draft Platform for Action. New York, Author.

Velásquez, A., L. Jiménez, A. Rechkemer, \& M. E. Planas (1997) "Algoritmo de oferta sistemática de servicios de salud reproductiva." Unpublished manuscript. Lima: INPPARES.

Velásquez, A., N. Ostolaza, T. Williams, \& J. Foreit (1996) "Encuesta de satisfacción de usuarias en la clínica Patres de INPPARES." Unpublished. Lima: INPPARES.

Vernon, R., \& E. Ottolenghi (1996) Algoritmo y guía para la oferta sistemática de servicios de salud reproductiva (ALGOSISSAR). Mexico: Population Council. 


\section{DATA POINTS FOR FIGURES}

Figure 1: First Visit

Mean Number of Services

Means Medians

Mean Amount in Soles

Means Medians

$\begin{array}{lll}\text { IEC } & 1.77 & 1.56 \\ \text { Control } & 1.80 & 1.54\end{array}$

$\begin{array}{lll}\text { IEC } & 40.73 & 40.22\end{array}$

$\begin{array}{lll}\text { Control } & 31.90 & 29.97\end{array}$

Figure 2: Follow-up

Mean Number of Services

Means Medians

$\begin{array}{lrr}\text { IEC } & .925 & .944 \\ \text { Control } & .564 & .573\end{array}$

Mean Amount in Soles

Means Medians

$\begin{array}{ll}\text { IEC } & 30.94623 .610 \\ \text { Control } & 18.47918 .016\end{array}$

